\title{
New Pharmacophore from the Stem Bark Fractions of Acacia decurrens (Willd), an Invasive South Africa Tree
}

\author{
Bamidele Joseph Okoli and Johannes Sekomeng Modise \\ Institute of Chemical and Biotechnology, Vaal University of Technology, Southern Gauteng Science and Technology Park, \\ Private Bag X021, Vanderbijlpark, No. 1911, 5 Moshoeshoe Street, Sebokeng 1983, South Africa \\ Correspondence should be addressed to Bamidele Joseph Okoli; bamideleo@vut.ac.za \\ and Johannes Sekomeng Modise; joe@vut.ac.za
}

Received 24 April 2017; Accepted 12 June 2017; Published 2 August 2017

Academic Editor: Isiaka A. Ogunwande

Copyright (C) 2017 Bamidele Joseph Okoli and Johannes Sekomeng Modise. This is an open access article distributed under the Creative Commons Attribution License, which permits unrestricted use, distribution, and reproduction in any medium, provided the original work is properly cited.

\begin{abstract}
The tolerance of Acacia decurrens, an invasive species, was exploited pharmacologically in this study. Phytochemical screening revealed important secondary metabolites. Importantly, the assay shows that ethyl acetate and methanol fractions are sources of phytochemicals compared to the hexane and chloroform fractions. A bioassay-guided in vitro assay of the extracts led to the eventual isolation of four bioactive compounds by column chromatography, identification, and characterisation with the aid of GCMS, UV-Vis, FTIR, and NMR. The antimicrobial screening by disc diffusion assay revealed $22.2 \%, 44.4 \%, 66.7 \%$, and $77.8 \%$ microbial inhibition by 2-methyl-octahydro-indene-4-carboxylic acid (AD1), 6-methyldecahydro-1H-phenanthren-9one (AD2), 8-hydroxytetradecahydro-chrysene-1-carb aldehyde (AD3), and 8,9-dihydroxy-7-(2-hydroxy-ethyl)-9,9a-hexahydro$1 \mathrm{H}, 3 \mathrm{H}$-2-thia-5a-aza cyclopenta[b]anthracen-6-one (AD4), respectively. Compounds AD3 and AD4 are the most potent antibacterial compounds against Gram-positive bacteria with MIC $12.5-6.25 \mu \mathrm{g} / \mathrm{ml}$. Antioxidant study of the compounds assayed with $\mathrm{DPPH}$ and $\mathrm{ABTS}^{*+}$ revealed that compound (AD4) is the most efficient DPPH radical scavenger with IC50 $30.07 \pm 0.31$ and $\mathrm{ABTS}^{\circ+}$ scavenging activity of $4363.2 \pm 452.4 \mu \mathrm{mol}$ of TE/gDW. This provides scientific information on four pharmacophores with phyto-antioxidants and antimicrobial potential, despite the classification of A. decurrens as a Category 2 invasive plant by the National Water Act.
\end{abstract}

\section{Introduction}

Invasive species are flora introduced into a foreign environment from their native host region and with significant consequences on the available resources in the host region [1]. The chances of an invasive species establishing dominance in a new environment are minuscule, but research has proven that once they do, the economic damage can be enormous [2]. Literature has shown that invasive species are responsible for threat on indigenous species, although some other biotic and abiotic factors might contribute [3].

Acacia (wattle) is native shrubs and trees to Australia, from the subfamily of Mimosoideae of the family Fabaceae, due to its prolific nature being found in all terrestrial habitats [4]. They are classified as a Category 2 invasive plant by the Act on Alien and Invasive Species Regulations of South Africa [5]; such exempted flora does require a permit to be introduced to the environment [6].
Indigenous wildlife may not have the potentials of combating or competing against invasive species that has no predators on the food chain within the new environment [7]; however, this phytotolerance can be exploited for its pharmacological activity against infections of the region. The plant parts have various applications in its native country Australia: the flowers are edible and the seed pods are used for the production of green dye, being grown for firewood or as a fast-growing windbreak or shelter tree. The gum from the trunk is used as a low-quality gum arabic [8].

According to the report of Tewari and Jindal [9], O-Me derivatives of the dietary supplements, 2,3,4,6-tetra-O-methyl-D-galactose, 2,3-di-O-Methyl-L-arabinose, 2,3,4-tri-Omethyl-D-galactose, and 2,4-di-O-methyl-D-galactose, were isolated from A. decurrens gum. Also, two novel diterpenoids, 11,14,15-trihydroxy-12-methoxy-20-oxo-8,11,13-abietatrien-7one and 10,11,14-trihydroxy-18-acetoxymethylene-12-methoxy-8,11,13-abietatrien-7-one, with selective inhibitory 
activity against MCF-7 and HT-29 cell lines, were isolated from the root extract of $A$. decurrens [10]. In addition to the novel bioactive compounds isolated, the recent upsurge in pharmacological potentials for phytoantioxidants, phytoantimicrobial pharmacophore, and tolerance of $A$. decurrens for native invader has been a source of motivation for the study of invasive vegetation as a source of the lead compound [8]. The selection of $A$. decurrens is not solely dependent on ethnopharmacological knowledge or traditional uses but by direct testing and bioassay-guided isolation of compounds [11]. The generic protocol for the drug discovery from natural products is employed in the study using bioassay-guided in vitro testing of the plant extracts and eventual isolation and identification of the bioactive compounds (see graphical abstract).

\section{Experimental}

2.1. Chemicals. The reagents and chemicals used in this study are from Sigma-Aldrich Chemicals Co., St. Louis, MO, USA, and are of analytical grade.

2.2. Collection and Extraction of A. decurrens Stem Bark. The fresh stem bark of $A$. decurrens was harvested around October 2016 near Vaal Dam Road, Heidelberg $\left(26.5033^{\circ} \mathrm{S}\right.$, $28.4397^{\circ} \mathrm{E}$ ), South Africa, diced, and dried at an ambient temperature at a relatively low humidity. Authentication of the of $A$. decurrens stem bark was carried out by the South Africa National Biodiversity Institute, Pretoria, and voucher specimen number: 1200-1, and was deposited at Pretoria National Botanical Garden. The extraction was performed by serial maceration using $4 \mathrm{~L}$ of each solvent: hexane, chloroform, ethyl acetate, and methanol with slight agitation at $111 \mathrm{revs} / \mathrm{min}$ for seven days. The solvents were removed using a rotary evaporator and the yield of the extracts was determined.

\subsection{Qualitative and Quantitative Phytochemical Screening.} The fractions were analyzed for the presence of secondary metabolites using standard procedures. The total phenolic content (TPC) was determined, and the results were expressed in mg of gallic acid per $g$ of the sample [12]. The total flavonoids (TFC) were measured and expressed as mg of rutin equivalents per $\mathrm{g}$ of the sample [13]. The tannin content (TC) measured and expressed as mg of tannin per $g$ of the sample [14], and also the alkaloid, saponins, and terpenoids contents were determined and expressed in percentage [1517].

2.4. Fractionation and Isolation of Compounds. The fractionation of the crude extracts was conducted on a Si-gel column of $640 \mathrm{~mm}$ by $60 \mathrm{~mm}$ with various solvent systems. The obtained bioactive fractions of the extracts were further subjected to subfractionation on a Si-gel column of $330 \mathrm{~mm}$ by $30 \mathrm{~mm}$ for isolation. Figure 1 is a summary of the fractionation, isolation, and purification of bioactive compounds from the extracts.
2.5. GC-MS Analysis of Compounds. The first step involves the solubilization of compounds $\mathrm{AD} 1$ and $\mathrm{AD} 2$ in chloroform and $\mathrm{AD} 3$ and $\mathrm{AD} 4$ in acetone prior to introduction into the GC injection port. The retention time and molecular ion determination were carried out on Clarus 500 PerkinElmer Gas Chromatograph equipped with an Elite5 (100\% dimethylpolysiloxane) column coupled to a mass spectrometer detector. The initial column temperature is set at $110^{\circ} \mathrm{C}$ and held for $2 \mathrm{~min}$ and the oven temperature increased at a rate of $5^{\circ} \mathrm{C} / \mathrm{min}$, to $230^{\circ} \mathrm{C}$, and held for $9 \mathrm{~min}$. The helium $(\mathrm{He})$ flow rate was maintained at $1 \mathrm{ml} / \mathrm{min}$, while keeping the injection port temperature at $250^{\circ} \mathrm{C}$. The injection of the compounds was by split mode method of $10: 1$ with a mass scan range of $45-450(\mathrm{~m} / \mathrm{z})$.

2.6. Spectroscopic Analysis of Compounds. Spectroscopic studies were carried out on the compounds by scanning the UV-Vis region using PerkinElmer Spectrophotometer and identification of functional groups by using VERTEX 80 FTIR Spectrophotometer and the 1D and 2D; the characterization was carried out on Agilent VnmrJ3 Spectrometer operating at $400 \mathrm{MHz}$.

2.7. Inoculums and Inoculation Procedure. Stock culture test organisms maintained at $4^{\circ} \mathrm{C}$ on slants of nutrient agar were obtained from the Biotechnology Department, Vaal University of Technology, South Africa. The growth method was employed in the standardisation of the inoculum density to achieve a concentration of $1.5 \times 10^{8} \mathrm{CFU} / \mathrm{ml}$. The agar plates were cultured from colonies in a Mueller-Hinton broth and incubated at $37^{\circ} \mathrm{C}$ to $0.5 \mathrm{McF}$ arland standard [18]. Furthermore, the inoculum suspension was used within a quarter of an hour to avoid any change in the size or loss of viability [19]. A uniform streaking of the dry Mueller-Hinton agar plate surface was conducted twice with standardised bacterial inoculum suspension.

2.8. Preparation of Compound Impregnated Discs. Sensitivity discs of $6 \mathrm{~mm}$ diameter were immersed in stock solutions of each compound prepared by dissolving 50,000 $\mu \mathrm{g}$ of the compound in $5 \mathrm{ml}$ of dimethyl sulfoxide [20]. The disc was sterilised by autoclaving at $121^{\circ} \mathrm{C}$ for 15 minutes and impregnated with $10 \mathrm{mg} / \mathrm{ml}$ of each compound. Dimethyl sulfoxide-loaded discs (negative controls), ampicillin (positive controls), and compound impregnated discs were dried in an incubator at $45^{\circ} \mathrm{C}$ for $24 \mathrm{~h}$ before the application on the bacterial lawn [21]. The disc diffusion method was carried out to investigate the in vitro sensitivity of Micrococcus luteus (ATCC 26883), Staphylococcus aureus (ATCC 25923), Escherichia coli (NCTC 11954), Salmonella typhi (ATCC 29692), Klebsiella pneumonia (BAA 1706), Shigella sonnei (ATCC 25931), Staphylococcus epidermis (ATCC 12228), Listeria monocytogenes (ATCC(R) BAA-751TM), and Enterococcus faecalis (ATCC 22735) against the compounds. The analysis was performed in triplicate.

2.9. Minimum Inhibitory Concentration (MIC). Microorganism sensitive compounds were screened to determine 


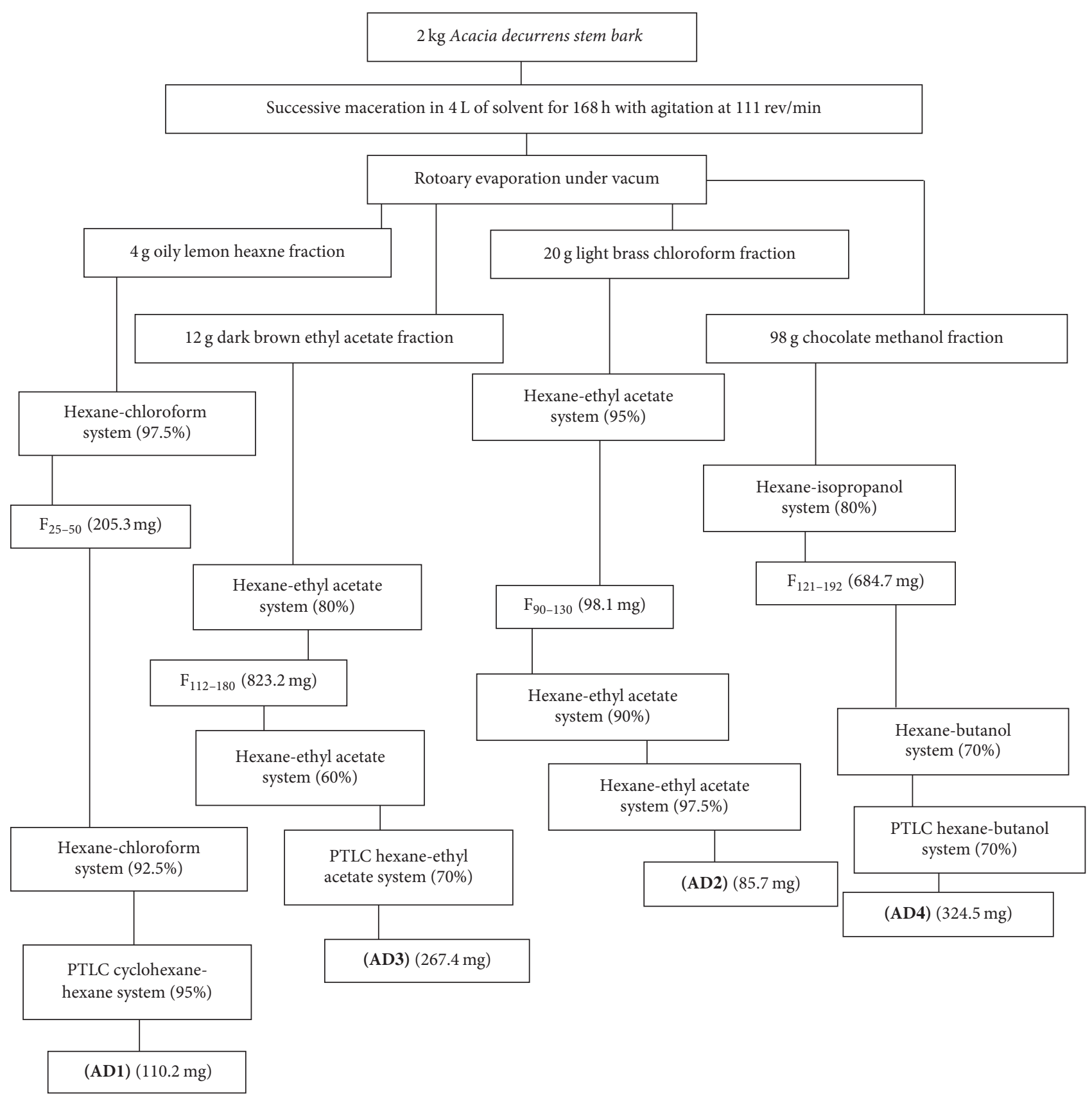

FIGURE 1: A brief summary of the general fractionation, isolation, and purification of bioactive compounds from the extracts.

the minimum inhibitory concentration by broth microdilution method [22]. The 12 wells of each row were filled with $0.5 \mathrm{ml}$ sterilised Mueller-Hinton agar. To wells 3-12 sequentially, an additional $0.5 \mathrm{ml}$ of a mixture of agar and compounds was serially diluted to create a concentration of $100-0.3906 \mu \mathrm{g} / \mathrm{mL}$. The first well served as growth control and well 2 as an antibiotic control (ampicillin) with MIC of $3.125 \mu \mathrm{g} / \mathrm{mL}$. The incubation of the deep wells was for $24 \mathrm{~h}$ at $37^{\circ} \mathrm{C}$ and turbidity was measured after $24 \mathrm{~h}$ at $600 \mathrm{~nm}$ using a PerkinElmer UV-Vis Spectrophotometer to determine the MIC. These tests were performed in triplicate.
2.10. DPPH Radical Scavenging Activity. The method of Blois with some modifications was applied to evaluate the ability of the compounds to scavenge the DPPH radicals [23]. Freshly prepared $300 \mu \mathrm{l}$ of $0.05 \mathrm{mM}$ methanolic solution of $\mathrm{DPPH}$ was added to $60 \mu \mathrm{l}$ of 2-methyl-octahydro-indene-4-carboxylic acid (AD1), 6-methyldecahydro-1H-phenanthren-9one (AD2), 8-hydroxytetradecahydro-chrysene-1-carbaldehyde (AD3), 8,9-dihydroxy-7-(2-hydroxy-ethyl)hexahydro$1 \mathrm{H}, 3 \mathrm{H}$-2-thia-5a-azacyclo penta[b] anthracen-6-one (AD4), ascorbic acid, and quercetin of different concentrations $(50-250 \mu \mathrm{g} / \mathrm{mL})$. Moreover, the mixture was vortexed and 
TABLE 1: Nature of the extracts and recovery yield/g of $A$. decurrens stem bark.

\begin{tabular}{lccc}
\hline Menstruum & Physical nature & Colour & Recovery yield/g \\
\hline Hexane & Oily & Lemon & $0.21 \pm 0.31$ \\
Chloroform & Solid & Light brass gold & $1.20 \pm 0.05$ \\
Ethyl acetate & Solid & Dark brown & $0.63 \pm 0.01$ \\
Methanol & Solid & Chocolate & $4.72 \pm 0.04$ \\
\hline
\end{tabular}

TABLE 2: Qualitative screening of the stem bark of A. decurrens of extracts.

\begin{tabular}{|c|c|c|c|c|}
\hline \multirow{2}{*}{ Phytochemical } & \multicolumn{4}{|c|}{ Fractions } \\
\hline & Hexane & Chloroform & Ethyl acetate & Methanol \\
\hline Alkaloids & + & ++ & - & - \\
\hline Glycosides & + & +++ & +++ & +++ \\
\hline Phenols & - & +++ & +++ & ++ \\
\hline Saponins & - & - & ++ & +++ \\
\hline Terpenoids & ++ & ++ & +++ & +++ \\
\hline Tannins & ++ & +++ & +++ & +++ \\
\hline Flavonoids & - & - & +++ & +++ \\
\hline
\end{tabular}

- , absent; +, low in abundance; ++, moderate in abundance; +++, high in abundance.

allowed for $30 \mathrm{~min}$ at $28^{\circ} \mathrm{C}$ in the absence of light. Then changes in the absorbance of the compounds were measured at $517 \mathrm{~nm}$ using a UV-Vis spectrophotometer. The comparative scavenging potentials of the compounds and standard antioxidants (quercetin and ascorbic acid) were expressed using the formula:

$$
\% \text { inhibition }=\frac{\left(A_{B}-A_{A}\right) \times 100}{A_{B}},
$$

where $A_{A}$ and $A_{B}$ are the absorbance of the test and blank, respectively. The $\mathrm{IC}_{50}(\mu \mathrm{M})$ was calculated using linear regression analysis. All analyses were carried out in triplicate.

2.11. Total Antioxidant Activity by $A_{B T S}{ }^{\bullet+}$ Decolourization Assay. In the method of Siddhuraju and Manian [24], the total antioxidant activity of the compounds was measured by the decolourization of ABTS $^{\bullet+}$. Exactly $7 \mathrm{mM}$ of 2,2'-azinobis(3-ethylbenzothiazoline-6-sulfonic acid and $2.45 \mathrm{mM}$ of potassium persulfate were prepared in distilled water, and the mixture was allowed to stand in the dark at ambient temperature for $24 \mathrm{~h}$ to generate the $\mathrm{ABTS}^{\bullet+}$. After incubation for $10 \mathrm{~h}$ at $28^{\circ} \mathrm{C}$ in the dark, the bluish green $\mathrm{ABTS}^{\circ+}$ colour was produced. However, the ABTS cation radical solution was diluted with distilled $\mathrm{H}_{2} \mathrm{O}$ to an absorbance of 1.00 at $734 \mathrm{~nm}$. The $3 \mathrm{~mL}$ of the generated ABTS $^{\bullet+}$ solution was mixed with $30 \mu \mathrm{L}$ of the compounds and Trolox (control). The antioxidant potential was expressed as the concentration of Trolox $(\mu \mathrm{mol} / \mathrm{g})$, having the equivalent antioxidant activity of the compounds on dry weight basis. The absorbance was read at $734 \mathrm{~nm}$ exactly after $30 \mathrm{~min}$.

\section{Results and Discussion}

3.1. Influence of Menstruum on the Recovery Yield of Compounds. The fractions obtained were different in colours and nature and the percentage yields were recorded. The methanolic fraction has a higher yield compared to the yield of chloroform, ethyl acetate, and hexane (Table 1).

This result implies that most of the secondary metabolites are hydrophilic in nature and consistent with the literature report which confirms methanol as the most suitable solvent for extraction of the polar secondary metabolite [25]. There has been a report that polarity significantly affects the recovery yields of the secondary metabolites from the plant [26].

3.2. Qualitative and Quantitative Phytochemical Screening. The phytochemical screening of the fractions reveals the presence of terpenoids, phenols, tannins, flavonoids, saponins, and alkaloids. All the menstruum contains terpenoids and tannins; however, the saponins were found only in the methanolic fraction (Table 2).

The methanolic and ethyl acetate fractions contain about $85.7 \%$ of the tested secondary metabolites with a high degree of precipitation, while hexane menstruum contains moderately $57.1 \%$. The secondary metabolites identified have established pharmacological activities consequentially [27, 28 ], indicating that the stem bark contains health-enhancing metabolites, other than growing invasive classification [29].

The alkaloid contents of the chloroform are higher than observed in hexane fraction (Figure 2(a)). However, the $\%$ steroids found in the hexane fraction is greater than chloroform, ethyl acetate, and methanol fractions (Figure 2(c)). High alkaloid and steroid contents in solvents of polarity index of $0.1-4.1$ are an indication that they are primarily nonpolar, unlike the saponins which are richer in ethyl acetate compared to the methanol fraction (Figure 2(b)).

According to the literature, alkaloids, saponins, and steroids are potent antimicrobial compounds because of their ability to prevent the growth of a microorganism, activating 


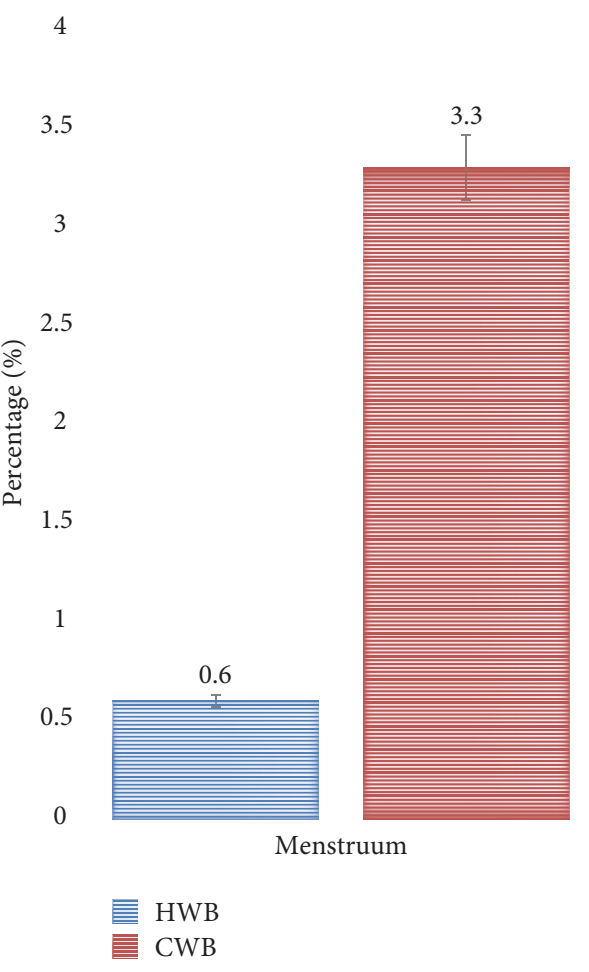

(a) \% alkaloid

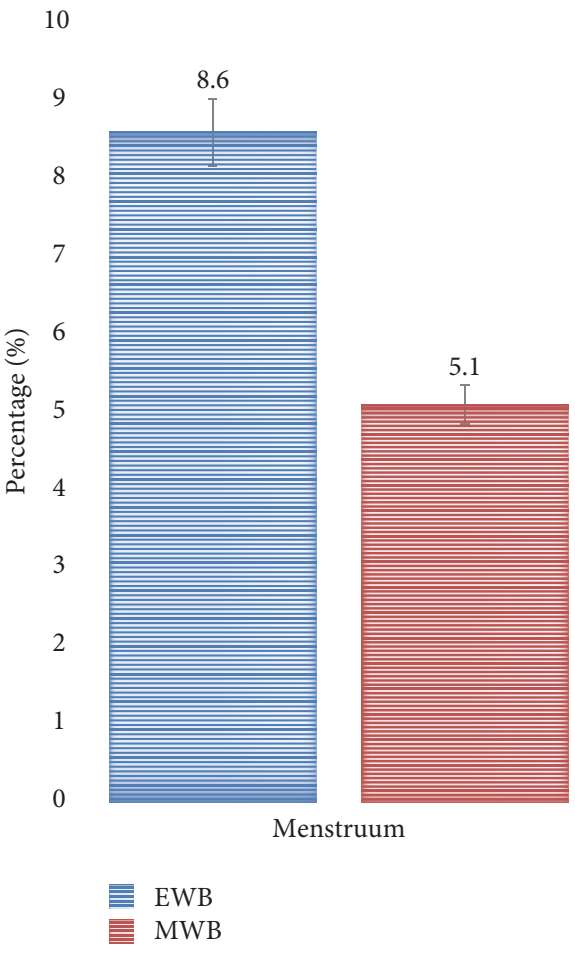

(b) \% saponins

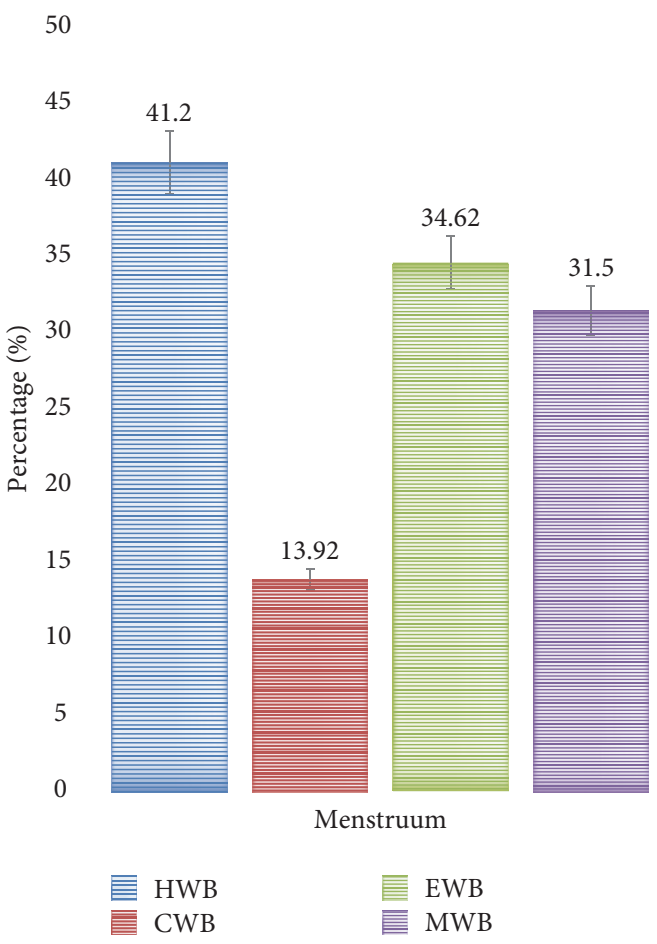

(c) \% terpenoids

FIGURE 2: HWB: hexane wattle bark; CWB: chloroform wattle bark; EWB: ethyl acetate wattle bark; MWB: methanol wattle bark.

perturbations of the membrane [30] and interfering with gene expression pathways and metabolic processes [31].

The total phenolic contents of the chloroform fraction are higher than those observed in ethyl acetate and methanol fractions, calculated from the calibration curve $\left(R^{2}=0.9903\right)$ (Figure 3(a)). The total flavonoid from the calibration curve $\left(R^{2}=0.9986\right)$ is slightly higher in the methanol than ethyl acetate fraction (Figure 3(b)). However, the calibration curve 


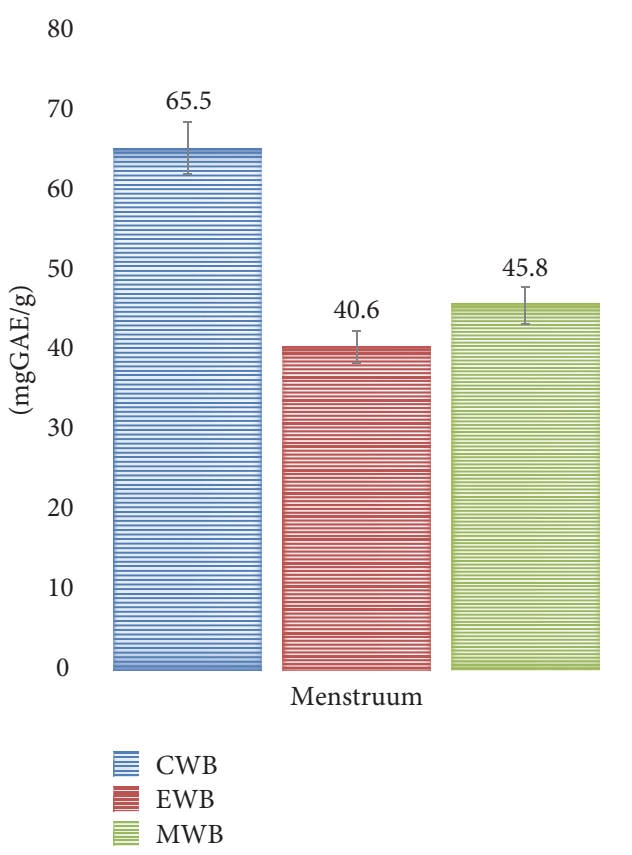

(a) TPC (mgGAE/g)

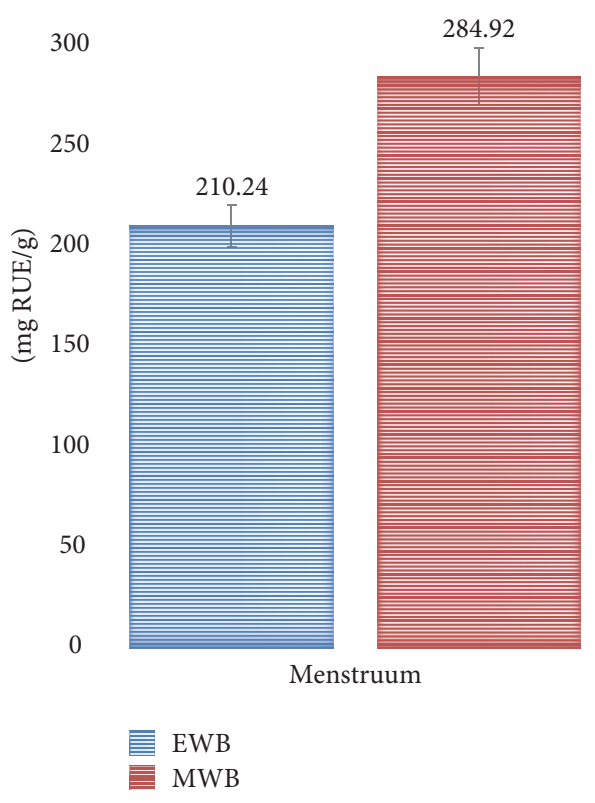

(b) TFC (mg RUE/g)

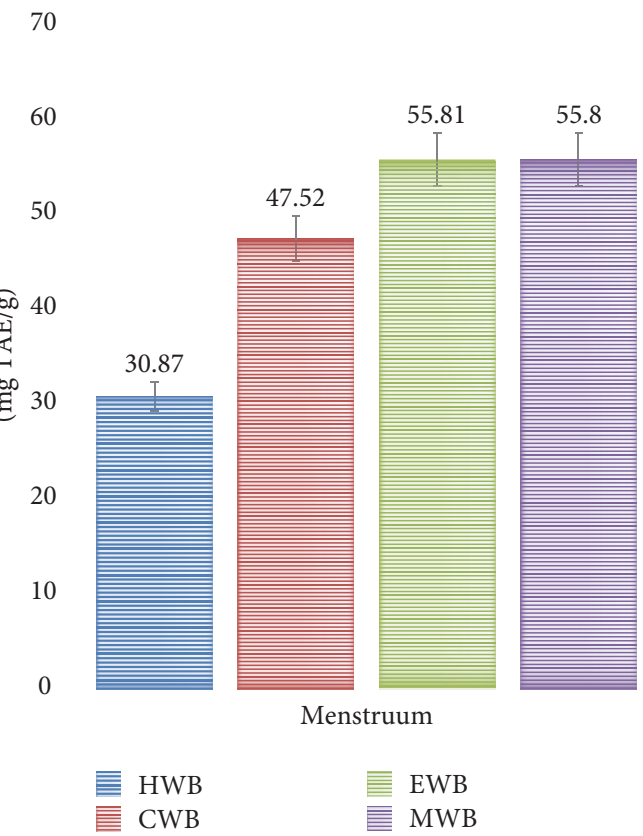

(c) TC (mg TAE/g)

FIGURE 3: HWB: hexane wattle bark extract; CWB: chloroform wattle bark extract; EWB: ethyl acetate wattle bark extract; MWB: methanol wattle bark extract.

$\left(R^{2}=0.9921\right)$ shows that the tannins are richer in solvents with polarity index 4.4-5.1, an indication of a highly polar class of tannins (Figure 3(c)). Reports have shown that phenols, flavonoids, and tannins have redox properties, which allow them to act as phytoantioxidants [32]. A significant rise in the level of the tannin and flavonoids extracted was observed as polarity changes with solvent. The observation above is because the tannins and flavonoids are water-soluble polyphenol class of compounds [33], and simple skeleton phenolic rings are connected by a propionic chain [34].

3.3. Characterization of 2-Methyl-octahydro-indene-4-carboxylic acid (AD1). 2-Methyl-octahydro-indene-4-carboxylic acid is obtained as a colourless oily compound $(110.2 \mathrm{mg}$ ) 
after purification (Rf: 0.84) with $\lambda \max 240(\varepsilon$ 130) (see Supporting File 1, in Supplementary Material available online at https://doi.org/10.1155/2017/1815278). The retention time (see Supporting File 2) and molecular mass are $10.8 \mathrm{~min}$ and $\mathrm{m} / z 182$ (see Supporting File 3), respectively.

The IR stretching vibration at $3293.87(\mathrm{~s}) \mathrm{cm}^{-1}$ is an O$\mathrm{H}$ of the carboxylic acid, and 2952.67(w) and 2843.39(w) are the $\mathrm{sp}^{3} \mathrm{C}-\mathrm{H}$ of an alkane and $\mathrm{C}=\mathrm{O}$ of a carboxylic acid at $1710.15(\mathrm{~m})$. The $\mathrm{sp}^{2} \mathrm{C}-\mathrm{H}$ bending vibrations of the alkane are at $1450.34(\mathrm{w})$ and $1410.80(\mathrm{w}) \mathrm{cm}^{-1}$, and $1113.28(\mathrm{w})$ and $1014.66(\mathrm{w}) \mathrm{cm}^{-1}$ are the $\mathrm{C}-\mathrm{O}$ stretching vibrations of carboxylic acid (see Supporting File 4).

${ }^{1} \mathrm{H}$ NMR $\delta_{\mathrm{H}}\left(400 \mathrm{MHz}, \mathrm{CD}_{3} \mathrm{Cl}\right)$ indicates carboxylic acid proton at $11.312(1 \mathrm{H}, \mathrm{s}, \mathrm{OH}) \mathrm{ppm}$ and methyl and methine protons at $2.15(2 \mathrm{H}, \mathrm{m}, 2-\mathrm{H}), 1.74(1 \mathrm{H}, \mathrm{m}, 10-\mathrm{H}), 1.40(2 \mathrm{H}, \mathrm{m}$, $2-\mathrm{H}), 1.41(1 \mathrm{H}, \mathrm{m}, 6-\mathrm{H}), 1.24(2 \mathrm{H}, \mathrm{m}, 2-\mathrm{H})$, and $0.87(3 \mathrm{H}, \mathrm{m}$, 11-H) ppm (see Supporting File 5).

${ }^{13} \mathrm{C}-\mathrm{NMR} \delta_{\mathrm{c}}\left(400 \mathrm{MHz}, \mathrm{CD}_{3} \mathrm{Cl}\right)$ indicates one methyl $\left(\mathrm{CH}_{3}\right)$ carbon at $19.68(\mathrm{C}-11) \mathrm{ppm}$, five methylene $\left(\mathrm{CH}_{2}\right)$ carbons at 32.74 (C-7), 30.04 (C-9), 29.38 (C-5), 26.89 (C3), and 22.70 (C-4) ppm, four methine carbons at 37.09 (C2), 31.93 (C-6), 30.87 (C-10), and 29.71 (C-8) ppm, and one quaternary carbon at $178.14(\mathrm{C}-1) \mathrm{ppm}$. Also observed is carboxylic acid carbon resonating at 178.14 (C-1) ppm, and a methine carbon at $37.09(\mathrm{C}-2)$ is attached to the carboxylic acid carbon (see Supporting File 6).

The HSQC spectrum shows a correlation between the protons at $2.15(2 \mathrm{H}, \mathrm{m}, 2-\mathrm{H})$ and $1.74(1 \mathrm{H}, \mathrm{m}, 10-\mathrm{H})$ and the methylene carbon at 32.74 (C-7) and 31.93 (C-6) ppm (see Supporting File 7). COSY data reveals a correlation between the protons at $2.15(2 \mathrm{H}, \mathrm{m}, 2-\mathrm{H})$ and $1.74(1 \mathrm{H}, \mathrm{m}, 10-\mathrm{H}) \mathrm{ppm}$ to the protons at $1.41(1 \mathrm{H}, \mathrm{m}, 6-\mathrm{H})$ and $1.24(2 \mathrm{H}, \mathrm{m}, 2-\mathrm{H}) \mathrm{ppm}$ (see Supporting File 8).

The HMBC shows that the proton at $11.312(1 \mathrm{H}, \mathrm{s}, \mathrm{OH})$ $\mathrm{ppm}$ is two bonds away from the carbon at 178.14 (C-1) ppm and three bonds away from the carbon at $37.09 \mathrm{ppm}$. Another notable correlation is between methine proton at $2.15(2 \mathrm{H}$, $\mathrm{m}, 2-\mathrm{H}) \mathrm{ppm}$ and the carbons at 30.87 (C-10) and 26.89 (C-3) ppm which are two bonds away (see Supporting File 9). The above spectroscopic data confirms structure as AD1 (Scheme 1) with a molecular formula of $\mathrm{C}_{11} \mathrm{H}_{18} \mathrm{O}_{2}$.

3.4. Characterization of 6-Methyldecahydro-1H-phenanthren9-one (AD2). 6-Methyldecahydro-1H-phenanthren-9-one was isolated as a white wax $(87.5 \mathrm{mg})$, melting point: $96-98^{\circ} \mathrm{C}$, after purification (Rf: 0.81). The UV-Vis profile revealed peak at $\lambda \max 240 \mathrm{~nm}(\varepsilon 200)$ (see Supporting File 10).

The IR stretching vibrations at 2954.72(w), 2920.47(s), and 2851.24(s) are the $\mathrm{sp}^{3} \mathrm{C}-\mathrm{H}$ of alkane, and $\mathrm{C}=\mathrm{O}$ of a ketone at $1723(\mathrm{~s}), 1640(\mathrm{~m})$, and $1650(\mathrm{~m})$ is $\mathrm{sp}^{2} \mathrm{C}=\mathrm{C}$ of an alkene. The bending vibrations of alkane $\mathrm{sp}^{2}$ and $\mathrm{sp}^{3} \mathrm{C}-\mathrm{H}$ are at $1462.67(\mathrm{~m}) \mathrm{cm}^{-1}$ and $1377.32(\mathrm{~m}) \mathrm{cm}^{-1}$, respectively (see Supporting File 11).

${ }^{1} \mathrm{H}$ NMR $\delta_{\mathrm{H}}\left(400 \mathrm{MHz}, \mathrm{CD}_{3} \mathrm{Cl}\right)$ indicates $3.47(2 \mathrm{H}, \mathrm{d}$, $\left.\mathrm{CH}_{2}\right), 1.71(1 \mathrm{H}, \mathrm{m}, \mathrm{CH}), 1.46(1 \mathrm{H}, \mathrm{m}, \mathrm{CH}), 1.30\left(2 \mathrm{H}, \mathrm{m}, \mathrm{CH}_{2}\right)$, $1.23\left(2 \mathrm{H}, \mathrm{m}, \mathrm{CH}_{2}\right), 1.08\left(2 \mathrm{H}, \mathrm{d}, \mathrm{CH}_{2}\right)$, and $0.92\left(3 \mathrm{H}, \mathrm{d}, \mathrm{CH}_{3}\right)$ $\mathrm{ppm}$. It establishes the presence of methyl at $0.92\left(3 \mathrm{H}, \mathrm{d}, \mathrm{CH}_{3}\right)$ ppm, methylene protons at $3.47\left(2 \mathrm{H}, \mathrm{d}, \mathrm{CH}_{2}\right), 1.30(2 \mathrm{H}, \mathrm{m}$,

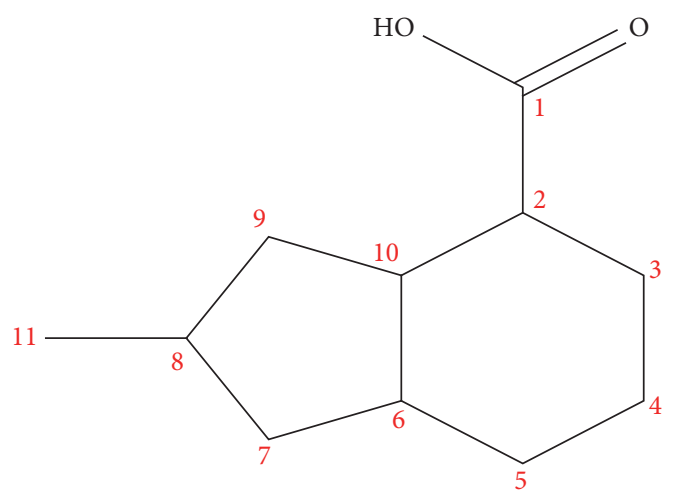

(AD1)

SCHEME 1

$\left.\mathrm{CH}_{2}\right), 1.23\left(2 \mathrm{H}, \mathrm{m}, \mathrm{CH}_{2}\right), 1.08\left(2 \mathrm{H}, \mathrm{d}, \mathrm{CH}_{2}\right)$, and methine proton at $1.71(1 \mathrm{H}, \mathrm{m}, \mathrm{CH})$ and $1.46(1 \mathrm{H}, \mathrm{m}, \mathrm{CH}) \mathrm{ppm}$ (see Supporting File 12).

${ }^{13} \mathrm{C}$-NMR $\delta \mathrm{c}\left(400 \mathrm{MHz}, \mathrm{CD}_{3} \mathrm{Cl}\right)$ indicates the presence of fifteen carbon atoms with the carbon peaks resonating at 207.04 (C-1), 157.46 (C-7), 138.34 (C-2), 39.01 (C-14), 37.05 (C6), 32.70 (C-4), 31.89 (C-8), 30.89 (C-5), 29.10 (C-13), 29.66 (C-12), 29.63 (C-9), 29.33 (C-10), 27.04 (C-11), 22.66 (C-3), and 19.67 (C-15) ppm (see Supporting File 13). ${ }^{13} \mathrm{C}-\mathrm{NMR}$ reveals the presence of one methyl group at $\delta \mathrm{c} 19.67$ (C-15), three methine carbons at $\delta \mathrm{c} 39.01$ (C-14), 37.05 (C-6), and $32.70(\mathrm{C}-4) \mathrm{ppm}$, eight methylene carbons at $\delta \mathrm{c} 31.89$ (C-8), 30.89 (C-5), 29.10 (C-13), 29.66 (C-12), 29.63 (C-9), 29.33 (C10), $27.04(\mathrm{C}-11)$, and $22.66(\mathrm{C}-3) \mathrm{ppm}$, and three quaternary carbons at $\delta \mathrm{c} 207.04(\mathrm{C}-1), 157.46(\mathrm{C}-7)$, and 138.34 (C-2) $\mathrm{ppm}$. The $\mathrm{C}=\mathrm{O}$ stretching vibration of a ketone as observed in the FTIR spectrum at $1705.21 \mathrm{~cm}^{-1}$ is resonating at 207.04 (C-1) ppm; however, the peaks at 157.46 (C-7) and 138.34 (C2) ppm are olefinic carbons corresponding to the stretching vibrational frequencies at 1640.01 and $1650.11 \mathrm{~cm}^{-1}$ on the FTIR spectrum (see Supporting File 11).

The HSQC shows a correlation between the proton at $\delta 3.47\left(2 \mathrm{H}, \mathrm{d}, \mathrm{CH}_{2}\right) \mathrm{ppm}$ and the carbon peak at 39.01 (C14) ppm (see Supporting File 14). The ${ }^{1 \mathrm{H}-1 \mathrm{H}} \mathrm{COSY}$ spectrum shows that the methylene proton at $3.47\left(2 \mathrm{H}, \mathrm{d}, \mathrm{CH}_{2}\right)$ and the methine proton at $1.71(1 \mathrm{H}, \mathrm{m}, \mathrm{CH}) \mathrm{ppm}$ are in the same chemical environment (see Supporting File 15).

The heteronuclear multiple bond correlation experiment reveals the correlations between carbons signals at 207.04 (C1), 157.46 (C-7), and 138.34 (C-2) ppm and the proton at 3.47 $\left(2 \mathrm{H}, \mathrm{d}, \mathrm{CH}_{2}\right)$ ppm (see Supporting File 16).

The GCMS analysis revealed a retention time of $15.98 \mathrm{~min}$ (see Supporting File 17) and a molecular ion peak at 218 (see Supporting File 18) which is in agreement with the molecular formula of $\mathrm{C}_{15} \mathrm{H}_{22} \mathrm{O}$. The molecular structure of 6-methyldecahydro-1H-phenanthren-9-one based on the spectroscopic information above is deduced to be AD2 (Scheme 2).

3.5. Characterization of 8-Hydroxytetradecahydro-chrysene-1carbaldehyde (AD3). 8-Hydroxytetradecahydro-chrysene-1carbaldehyde is a white needle $(267.4 \mathrm{mg})$, melting point: 


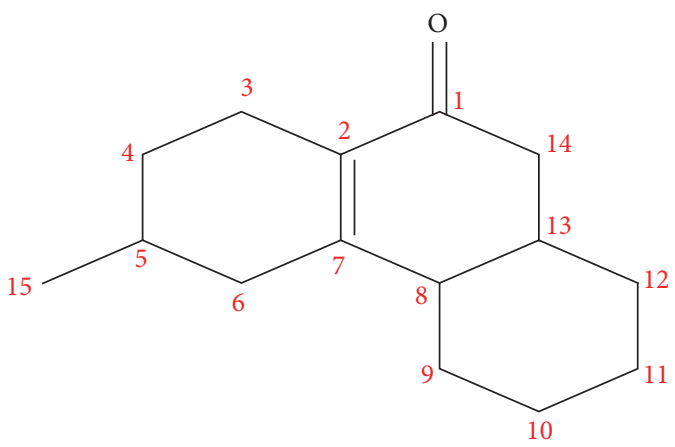

(AD2)

SCHEME 2

178-180 ${ }^{\circ} \mathrm{C}$, after purification: Rf: 0.68 with $\lambda_{\max } 240 \mathrm{~nm}$ (1.354) (see Supporting File 19). The retention time is $21.58 \mathrm{~min}$ (see Supporting File 20) and a molecular ion is at $\mathrm{m} / z 396$ (see Supporting File 21).

The IR spectrum of 8-hydroxytetradecahydro-chrysene1-carbaldehyde reveals the presence of - $\mathrm{OH}$ stretching vibration of alcohol at $3274 \mathrm{~cm}^{-1}$, C-H of alkane $2968,2945,2919$, and $2853 \mathrm{~cm}^{-1}$ the $=\mathrm{C}-\mathrm{H}$ of aldehyde at $2869 \mathrm{~cm}^{-1}, \mathrm{C}=\mathrm{O}$ of aldehyde at $1735 \mathrm{~cm}^{-1}$, and two peaks of C-O of alcohol at 1190 and $1097 \mathrm{~cm}^{-1}$. The bending vibration at $1464 \mathrm{~cm}^{-1}$ is the C$\mathrm{H}$ of alkane and $1386 \mathrm{~cm}^{-1}$ of C-H of alkane (see Supporting File 22).

${ }^{1} \mathrm{H}$ NMR $\delta_{\mathrm{H}}\left(400 \mathrm{MHz}, \mathrm{CD}_{3} \mathrm{Cl}\right)$ showed the presence of an aldehyde proton at $9.67(1 \mathrm{H}, \mathrm{s}, 26-\mathrm{H}) \mathrm{ppm}$, two olefinic protons at $5.12(1 \mathrm{H}, \mathrm{t}, 12-\mathrm{H})$ and $5.20(1 \mathrm{H}, \mathrm{d}, 19-\mathrm{H}) \mathrm{ppm}$, oxymethine proton resonating at $3.20(1 \mathrm{H}, \mathrm{m}, 3-\mathrm{H}) \mathrm{ppm}$, and hydroxyl proton at $1.59(1 \mathrm{H}, \mathrm{s}, \mathrm{OH}) \mathrm{ppm}$ (see Supporting File 23).

${ }^{13} \mathrm{C}$ NMR data $\delta \mathrm{c}\left(400 \mathrm{MHz}, \mathrm{CD}_{3} \mathrm{Cl}\right)$ showed eight methine carbons at 38.73 (C-10), 37.09 (C-8), 31.07 (C-9), 27.14 (C-5), 55.11 (C-14), 78.96 (C-3), 120.13 (C-12), and 122.42 (C11) ppm, eight methylene at 18.34 (C-1), 23.67 (C-15), 23.50 (C-7), 25.97 (C-16), 26.10 (C-6), 28.05 (C-17), 34.69 (C-2), and $47.58(\mathrm{C}-4) \mathrm{ppm}$, and three quaternary carbons at 186.36 (C-19), 140.00 (C-13), and 145.18 (C-18) ppm. The ${ }^{13} \mathrm{C}$ NMR spectrum revealed the presence of a carbonyl carbon at 186.36 (C-19) ppm, four olefinic carbon atoms resonating at 120.13 (C-12), 122.42 (C-11), 140.00 (C-13), and 145.18 (C-18) ppm, and an oxymethine carbon peak at 78.96 (C-3) ppm (see Supporting File 24).

The HSQC assignment of the proton at $9.67(1 \mathrm{H}, \mathrm{s}$, $26-\mathrm{H}) \mathrm{ppm}$ to the carbonyl carbon at 186.36 (C-19) ppm is an indication that the proton is directly bonded. Also, the oxymethine proton at $3.20(1 \mathrm{H}, \mathrm{m}, 3-\mathrm{H})$ ppm shows correlation to carbon peak at $78.96(\mathrm{C}-3) \mathrm{ppm}$. The olefinic protons at $5.12(1 \mathrm{H}, \mathrm{t}, 12-\mathrm{H})$ and $5.20(1 \mathrm{H}, \mathrm{d}, 19-\mathrm{H}) \mathrm{ppm}$ show correlation to the carbon peaks at 120.13 (C-12) and 122.42 (C11), respectively (see Supporting File 25).

The COSY spectrum indicates that the olefinic protons at $5.12(1 \mathrm{H}, \mathrm{t}, 12-\mathrm{H})$ and $5.20(1 \mathrm{H}, \mathrm{d}, 19-\mathrm{H}) \mathrm{ppm}$ show correlation to the methine protons at 1.98 and $1.94 \mathrm{ppm}$. There is a correlation between the oxymethine proton at $3.20(1 \mathrm{H}, \mathrm{m}, 3-$ $\mathrm{H}$ ) ppm and the protons at 1.53 and $1.52 \mathrm{ppm}$ (see Supporting

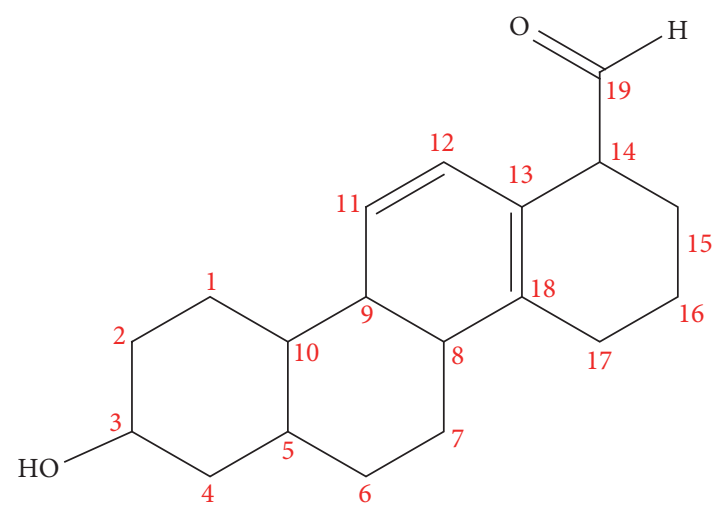

(AD3)

SCHEME 3

File 26). The aldehyde proton at $9.67(1 \mathrm{H}, \mathrm{s}, 26-\mathrm{H}) \mathrm{ppm}$ is three bonds away from the olefinic carbon peak at 145.18 (C-18) ppm. Also, the oxymethine proton peak at $3.20(1 \mathrm{H}$, $\mathrm{m}, 3-\mathrm{H}) \mathrm{ppm}$ shows correlation with 38.73 (C-10), 37.09 (C8), and $27.14(\mathrm{C}-5) \mathrm{ppm}$ methine protons and 18.34 (C-1) and 23.67 (C-15) methylene protons. The olefinic protons at $5.12(1 \mathrm{H}, \mathrm{t}, 12-\mathrm{H})$ and $5.20(1 \mathrm{H}, \mathrm{d}, 19-\mathrm{H}) \mathrm{ppm}$ show multiple bond correlations to carbon peaks at 25.97 (C-16) and 26.10 (C-6) ppm (see Supporting File 27). The structure and molecular formulas of 8-hydroxytetradecahydro-chrysene-1carbaldehyde, inferred from the MS spectrum, $1 \mathrm{D}$ NMR, COSY, and HMBC spectra, are confirmed as AD3 (Scheme 3) and $\mathrm{C}_{19} \mathrm{H}_{42} \mathrm{O}_{2}$, respectively.

3.6. Characterization of 8,9-Dihydroxy-7-(2-hydroxy-ethyl)-9, 9a-hexahydro-1H,3H-2-thia-5a-azacyclo penta[b]anthracen6-one (AD4). 8,9-Dihydroxy-7-(2-hydroxy-ethyl)-9,9a-hexa-hydro-1H,3H-2-thia-5a-azacyclopenta[b] anthracen-6-one was isolated as a yellow semisolid $(324.5 \mathrm{mg})$, melting point: $212-214^{\circ} \mathrm{C}$, after purification Rf: 0.58 with a GC retention time of 23.25 mins (see Supporting File 28). The UV-Vis peak at $\lambda \max 240 \mathrm{~nm}(\varepsilon 1.333)$ (see Supporting File 29) and the mass spectrum revealed a molecular ion peak at $\mathrm{m} / z 333$ (see Supporting File 30).

On the IR spectrum, an $\mathrm{O}-\mathrm{H}$ stretching vibration of alcohol is observed at $3369.00(\mathrm{~m}) \mathrm{cm}^{-1}, \mathrm{sp}^{3} \mathrm{C}-\mathrm{H}$ stretching vibration at $2924(\mathrm{~m}) \mathrm{cm}^{-1}$, S-C stretching vibration at $2498(\mathrm{~m}) \mathrm{cm}^{-1}$, and $\mathrm{C}=\mathrm{O}$ stretching vibration of a tertiary amide at 1685 (s). Also, bending vibrations were observed at the fingerprint region at $1019(\mathrm{~s}) \mathrm{cm}^{-1}$ of $\mathrm{C}-\mathrm{O}$, aromatic $\mathrm{C}=\mathrm{C}$ overtone at $1610(\mathrm{~s})$ and $1407(\mathrm{~m}) \mathrm{cm}^{-1}$, and $\mathrm{C}-\mathrm{H}$ aromatic bending vibrations at 985(s), 942(s), 929(s), 900(s), 837(s), and $758(\mathrm{~s}) \mathrm{cm}^{-1}$ (see Supporting File 31 ).

${ }^{1} \mathrm{H}$ NMR $\delta_{\mathrm{H}}\left(400 \mathrm{MHz}, \mathrm{CD}_{3} \mathrm{OD}\right)$ indicated $6.04(1 \mathrm{H}, \mathrm{s}$, 2-H), $6.04(1 \mathrm{H}, \mathrm{s}, 13-\mathrm{H}), 3.98(2 \mathrm{H}, \mathrm{s}, 4-\mathrm{H}), 3.77(1 \mathrm{H}, \mathrm{m}, 10-\mathrm{H})$, $3.73(1 \mathrm{H}, \mathrm{dd}, 9-\mathrm{H}), 3.70(2 \mathrm{H}, \mathrm{s}, 15-\mathrm{H}), 3.70(2 \mathrm{H}, \mathrm{s}, 17-\mathrm{H}), 3.50$ $(2 \mathrm{H}, \mathrm{t}, 19-\mathrm{H}), 3.40(2 \mathrm{H}, \mathrm{dd}, 8-\mathrm{H}), 2.32(2 \mathrm{H}, \mathrm{d}, 11-\mathrm{H}), 1.96(1 \mathrm{H}$, $\mathrm{m}, 7-\mathrm{H}), 1.86(2 \mathrm{H}, \mathrm{m}, 18-\mathrm{H}), 1.84(1 \mathrm{H}, \mathrm{s}, 19-\mathrm{OH}), 1.79(1 \mathrm{H}, \mathrm{s}$, $8-\mathrm{OH})$, and $1.74(1 \mathrm{H}, \mathrm{s}, 9-\mathrm{OH}) \mathrm{ppm}$.

${ }^{13} \mathrm{C}-\mathrm{NMR} \delta \mathrm{c}(400 \mathrm{MHz}, \mathrm{Cd} 3 \mathrm{OD})$ indicated $176.72(\mathrm{C}-6)$, 138.45 (C-12), 136.83 (C-14), 133.11 (C-1), 130.61 (C-3), 128.46 


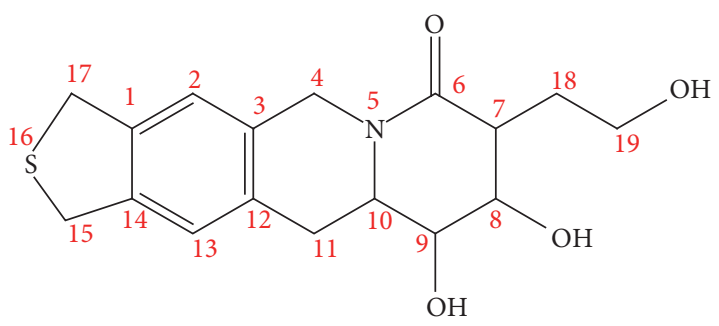

(AD4)

SCHEMe 4

(C-13), 128.42 (C-2), 75.29 (C-9), 74.80 (C-8), 60.17 (C-19), 54.43 (C-10), 47.71 (C-4), 40.72 (C-17), 40.53 (C-15), 38.13 (C7), 29.11 (C-11), and 27.79 (C-18) ppm.

The ${ }^{1} \mathrm{H}$ NMR spectrum revealed the presence of aromatic proton at $6.04(1 \mathrm{H}, \mathrm{s}, 2-\mathrm{H})$ and $6.04(1 \mathrm{H}, \mathrm{s}, 13-\mathrm{H}) \mathrm{ppm}$, oxy-methine proton resonating at $3.40(2 \mathrm{H}, \mathrm{dd}, 8-\mathrm{H}) \mathrm{ppm}$, thiomethine protons resonating $3.70(2 \mathrm{H}, \mathrm{s}, 15-\mathrm{H})$ and 3.70 $(2 \mathrm{H}, \mathrm{s}, 17-\mathrm{H}) \mathrm{ppm}$, and proton $\alpha$ to carbonyl at $1.96(1 \mathrm{H}, \mathrm{m}$, 7-H) ppm (see Supporting File 32).

The ${ }^{13} \mathrm{C}-\mathrm{NMR}$ spectrum showed seventeen carbon atoms of six methine $(\mathrm{CH})$ carbons at 38.13 (C-7), 74.80 (C-8), 75.29 (C-9), 54.43 (C-10), 128.46 (C-13), and 128.42 (C-2) ppm, six methylene $\left(\mathrm{CH}_{2}\right)$ at $40.72(\mathrm{C}-17), 40.53$ (C-15), $29.11(\mathrm{C}-$ 11) 47.71 (C-4), 60.17 (C-19), and 27.79 (C-18) ppm, and six quaternary carbon atoms at 133.11 (C-1), 130.61 (C-3), 138.45 (C-12), 136.83 (C-14), and 176.72 (C-6) ppm. The ${ }^{13} \mathrm{C}$ NMR spectrum revealed the carbonyl carbon of an amide at 176.72 (C-6) ppm and the presence of six aromatic carbon atoms resonating at $138.45(\mathrm{C}-12), 136.83$ (C-14), 133.11 (C-1), 130.61 (C-3), 128.46 (C-13), and 128.42 (C-2) ppm. Two oxymethine carbons peaked at 75.29 (C-9) and 74.80 (C-8) ppm and an oxymethylene peak appeared up field at 60.17 (C-19) ppm (see Supporting File 33).

The HSQC showed correlations between the aromatic carbons at $128.46(\mathrm{C}-13)$ and 128.42 (C-2) ppm and protons at $6.04(1 \mathrm{H}, \mathrm{s}, 2-\mathrm{H})$ and $6.04(1 \mathrm{H}, \mathrm{s}, 13-\mathrm{H}) \mathrm{ppm}$. Also, there is a connection between the two oxymethine carbons at 75.29 (C-9) and 74.80 (C-8) ppm and the protons at 3.98 (2H, s, 4$\mathrm{H})$ and $3.77(1 \mathrm{H}, \mathrm{m}, 10-\mathrm{H})$ ppm (see Supporting File 34$)$.

The COSY spectrum indicates that the aromatic protons at $6.04(1 \mathrm{H}, \mathrm{s}, 2-\mathrm{H})$ and $6.04(1 \mathrm{H}, \mathrm{s}, 13-\mathrm{H}) \mathrm{ppm}$ are three bonds away from the thiomethylene protons at $3.73(1 \mathrm{H}$, dd, 9-H) and $3.70(2 \mathrm{H}, \mathrm{s}, 15-\mathrm{H})$ ppm (see Supporting File 35). The HMBCAD showed that the peaks at $176.72(\mathrm{C}-$ 6), 138.45 (C-12), 136.83 (C-14), 133.11 (C-1), 130.61 (C-3), 128.46 (C-13), 128.42 (C-2), 74.80 (C-8), and 54.43 (C-10) ppm are close to the same chemical environment as the aromatic protons $6.04(1 \mathrm{H}, \mathrm{s}, 2-\mathrm{H})$ and $6.04(1 \mathrm{H}, \mathrm{s}, 13-\mathrm{H})$ ppm (see Supporting File 36 for full experimental data). The information from the 1D, HSQC, COSY, HMBCAD, and mass spectra of 8,9-dihydroxy-7-(2-hydroxy-ethyl)-9,9ahexahydro- $1 \mathrm{H}, 3 \mathrm{H}-2$-thia-5a-aza cyclopenta [b] anthracen-6one confirms a structure of AD4 (Scheme 4) and molecular formula $\mathrm{C}_{18} \mathrm{H}_{23} \mathrm{NO}_{3} \mathrm{~S}$.

3.7. Antimicrobial Potential of Compounds AD1-AD4. The inhibition effect of the compounds is tested on nine bacterial

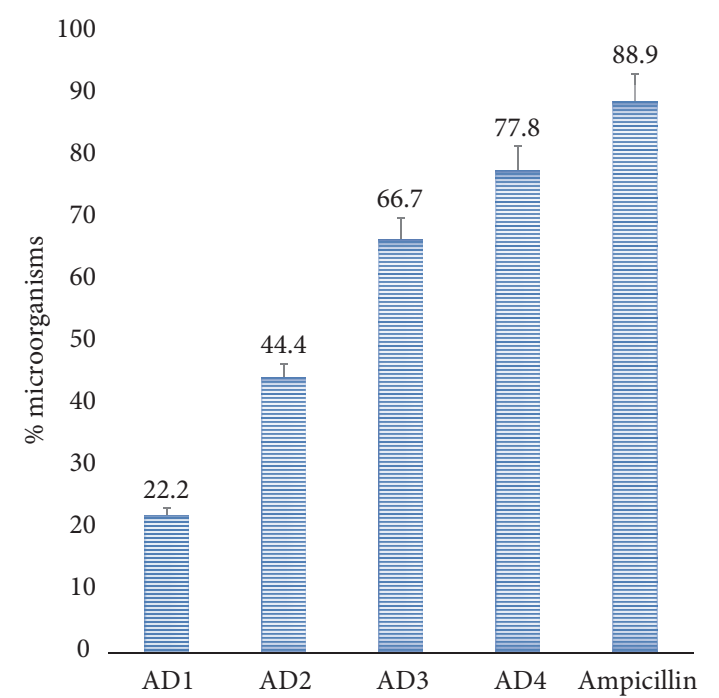

FIGURE 4: Antibacterial activity of the bioactive compounds.

strains, including six Gram-positive and three Gram-negative strains. The compounds $\mathrm{AD}(\mathbf{1}-\mathbf{4})$ have little inhibitory activity against Gram-negative strains, but the results on the six Gram-positive strains were significant. Compounds AD2, AD3, and AD4 were the most potent antimicrobial compounds inhibiting $44.4 \%, 66.7 \%$, and $77.8 \%$ of the tested microorganisms, respectively (Table 3 and Figure 4). On the other hand, compound AD1 has the lowest bacterial inhibition at $22.2 \%$ compared to the positive control and the other compounds.

Compound AD4 indicated the highest antimicrobial activity due to the presence of functional groups such as the thiol, hydroxyl, and amide. However, E. coli and S. sonnei were predominantly resistance, due to the production of $\beta$ lactamases as expected of Gram-negative organisms [35]; similar strength was observed for compounds AD2 and AD3.

For $\beta$-lactams to reach the binding proteins located in the inner membrane of the organism specific functional group is required. In this study, the bacterial cell production of $\beta$ lactamases was in insufficient concentration to tip the kinetics in favour of the destruction of compounds AD2, AD3, and AD4. Compound AD1 clearly was ineffective due to the absence of the primary functional groups by decreasing penetration or actively extruding the antimicrobial compound [36]. The breaching of the intact cell walls and membranes of the peptidoglycan and cytoplasmic layer of M. luteus, E. faecalis, and L. monocytogenes is also due to the type of functional groups on compounds AD2, AD3, and AD4. They induce cells to lyse and cause breakage of walls and membranes. M. luteus and L. monocytogenes were sensitive to all tested compounds despite the fact that these organisms survive oligotrophic environments for extended periods of time [37], confirming the possible use of the compounds for the treatment of opportunistic infection caused by $M$. luteus and $L$. monocytogenes in immunosuppressed patients.

The MIC of bioactive compounds (Table 4) revealed that 8-hydroxytetradecahydro-chrysene-1-carbaldehyde (AD3) and 8,9-dihydroxy-7-(2-hydroxy-ethyl)-9,9a-hexahydro-1H, 
TABLE 3: Sensitivity of the bioactive compounds against the test organisms.

\begin{tabular}{lccccc}
\hline Bacteria & $(\mathbf{1})$ & $\mathbf{( 2 )}$ & $\mathbf{( 3 )}$ & $\mathbf{( 4 )}$ & Ampicillin \\
\hline Staphylococcus aureus & - & - & - & + & - \\
Escherichia coli & - & - & + & + & + \\
Salmonella typhi & - & + & - & + & + \\
Klebsiella pneumoniae & - & + & + & - & + \\
Micrococcus luteus & + & - & + & + & + \\
Shigella sonnei & - & - & + & + \\
Staphylococcus epidermis & - & + & + & + \\
Listeria monocytogenes & + & + & & + \\
Enterococcus faecalis & - & + & & + \\
\hline
\end{tabular}

$(+)$ : susceptibility (inhibition zone $\geq 7 \mathrm{~mm})$; (-): absence of susceptibility.

TABLE 4: Minimum inhibitory concentration $(\mu \mathrm{g} / \mathrm{ml})$ of the bioactive compounds.

\begin{tabular}{|c|c|c|c|c|c|}
\hline Bacteria & (AD1) & (AD2) & (AD3) & (AD4) & Ampicillin \\
\hline Staphylococcus aureus & - & - & 12.5 & 12.5 & 12.5 \\
\hline Escherichia coli & - & - & - & - & - \\
\hline Salmonella typhi & - & 50 & 12.5 & 12.5 & 12.5 \\
\hline Klebsiella pneumoniae & - & - & - & - & 6.25 \\
\hline Micrococcus luteus & 50 & 50 & 12.5 & 12.5 & 6.25 \\
\hline Shigella sonnei & - & - & - & 25 & 6.25 \\
\hline Staphylococcus epidermis & - & - & 12.5 & 12.5 & 6.25 \\
\hline Listeria monocytogenes & 50 & 50 & 12.5 & 6.25 & 6.25 \\
\hline Enterococcus faecalis & - & 25 & 12.5 & 6.25 & 12.5 \\
\hline
\end{tabular}

3H-2-thia-5a-azacyclopenta[b]anthracen-6-one (AD4) exhibited remarkable antibacterial activity toward the tested bacterial strains.

Compound AD4 has a strong effect on L. monocytogenes and E. faecalis with MIC value of $6.25 \mu \mathrm{g} / \mathrm{ml}$, whereas compounds AD1 and AD2 displayed destitute bacteriostatic activity with MIC value of $50 \mu \mathrm{g} / \mathrm{ml}$. 8-Hydroxytetradecahydro-chrysene-1-carbaldehyde (AD3) also exhibited significant activity against $M$. luteus, S. aureus, S. typhi, S. epidermis, L. monocytogenes, and E. faecalis with MIC value of $12.5 \mu \mathrm{g} / \mathrm{ml}$. However, only two compounds 8-hydroxytetradecahydro-chrysene-1-carbaldehyde (AD3) and 8,9-dihydroxy-7-(2-hydroxy-ethyl)-9,9a-hexahydro-1H,3H-2-thia5a-azacyclopenta[b]anthracen-6-one (AD4) demonstrated strong anti-Gram-positive bacterial potential compared to ampicillin with MIC values ranging from 6.25 to $12.5 \mu \mathrm{g} / \mathrm{ml}$. These results indicate that the stem bark of $A$. decurrens can be useful for the development of antibiotic and can also be a bioactive scaffold for new antibacterial drugs.

3.8. In Vitro Antioxidant Activity. The antioxidant capacity of compounds $\mathbf{A D}(\mathbf{1 - 4})$ was evaluation in vitro [38, 39], using DPPH a stable free radical acceptor of electron or hydrogen radical. Compounds AD3 and AD4 had significant scavenging effects on the DPPH radical, indicated by a colour (Table 5). As the concentration of 8-hydroxytetradecahydrochrysene-1-carbaldehyde (AD3) and 8,9-dihydroxy-7-(2-hydroxy-ethyl)-9,9a-hexahydro-1H,3H-2-thia-5a-azacyclopenta[b] anthracen-6-one (AD4) increases from 50 to $250 \mu \mathrm{g} / \mathrm{mL}$, so is the electrons taken up by DPPH radical. The radical scavenging strength of the compounds is in the order ascorbic acid > 8,9-dihydroxy-7-(2-hydroxy-ethyl)-9,9a-hexahydro$1 \mathrm{H}, 3 \mathrm{H}$-2-thia-5a-azacyclopenta[b] anthracen-6-one (AD4) > quercetin $>$ 8-hydroxytetradecahydro-chrysene-1-carbaldehyde $($ AD3 $)>2$-methyl-octahydroindene-4-carboxylic acid (AD2) > 6-methyldecahydro-1H-phenanthren-9-one (AD1) with the $\mathrm{IC}_{50}$ (Table 5).

The study revealed that the 8-hydroxytetradecahydrochrysene-1-carbaldehyde (AD3) and 8,9-dihydroxy-7-(2-hydroxy-ethyl)-9,9a-hexahydro- $1 \mathrm{H}, 3 \mathrm{H}$-2-thia-5a-azacyclopenta[b]anthracen-6-one (AD4) were able to inhibit the potassium persulfate activity hence, reducing the production of $\mathrm{ABTS}^{\bullet+}$ and exhibited higher ABTS radical scavenging activity. However, 2-methyl-octahydro-indene-4-carboxylic acid (AD1) and 6-methyldeca hydro- $1 \mathrm{H}$-phenanthren-9-one (AD2) are relatively weak antioxidant (Table 5).

The ascorbic acid used as a control in this study readily forms dehydroascorbate which does not possess radical scavenging potentials, but it easily reverts to ascorbate radical by donating an electron to the radical [40]. The radical anions on the oligonucleotides DNA are always prone to the attack of polyhydroxy compounds such as quercetin, and this explains the observed activities of compounds AD4 and AD3. The comparable scavenging activity of compounds AD4 due to the presence of the polyhydroxy groups in the neighbourhood of the aromatic ring is enhanced by the inductive effect of neighbouring groups, consequently, having the ease at which the protons are donated compared to 
TABLE 5: Radical scavenging activity of the compounds from the stem bark of $A$. decurrens.

\begin{tabular}{lcc}
\hline Compounds & $\begin{array}{c}\text { DPPH radical scavenging activity } \\
\mathrm{IC}_{50} \text { values }(\mu \mathrm{g} / \mathrm{mL})\end{array}$ & ABTS $^{\bullet+}$ scavenging activity $(\mu \mathrm{mol}$ of TE/g DW) \\
\hline $\mathrm{AD} 1$ & $398.31 \pm 0.21$ & $1425.3 \pm 167.2$ \\
$\mathrm{AD} 2$ & $439.29 \pm 0.51$ & $1945.9 \pm 334.8$ \\
$\mathrm{AD} 3$ & $59.34 \pm 0.07$ & $3356.4 \pm 253.7$ \\
$\mathrm{AD} 4$ & $30.07 \pm 0.31$ & $4363.2 \pm 452.4$ \\
Ascorbic acid & $15.75 \pm 0.04$ & \\
Quercetin & $45.74 \pm 0.41$ & \\
\hline
\end{tabular}

quercetin and compounds AD3. 8-Hydroxytetradecahydrochrysene-1-carbaldehyde (AD3) being a tetracyclic steroid has an equally likely activity due to the long carbon chains, imposing a lipophilic property which plays a significant role in the radical scavenging activity [41]. 2-Methyl-octahydroindene-4-carboxylic acid (AD1) and 6-methyldecahydro$1 \mathrm{H}$-phenanthren-9-one (AD1) are weak phytoantioxidant compounds due to the absence of electron donating and polyhydroxy groups on the structure.

\section{Conclusion}

The findings from this study confirm ethyl acetate and methanol as the most efficient solvent for extracting potent phytoantioxidant and antimicrobial metabolites. The generic protocol for the drug discovery from the stem bark of $A$. decurrens based on straightforward testing led to the isolation and identification of 2-methyl-octahydro-indene-4-carboxylic acid (AD1), 6-methyldecahydro-1H-phenanthren-9-one (AD2), 8-Hydroxytetradecahydro-chrysene-1-carb aldehyde (AD3), and 8,9-dihydroxy-7-(2-hydroxy-ethyl)-9,9a-hexahydro-1H,3H-2-thia-5a-aza cyclo penta[b]anthracen-6-one (AD4). 8-Hydroxytetradecahydro-chrysene-1-carbaldehyde and 8,9-dihydroxy-7-(2-hydroxy-ethyl)-9,9a-hexahydro- $1 \mathrm{H}$, $3 \mathrm{H}-2$-thia-5a-azacyclopenta[b]anthracen-6-one have promising antimicrobial and antioxidant activity and could be new lead compounds. The free radical scavenging activity of 8,9dihydroxy-7-(2-hydroxy-ethyl)-9,9a-hexahydro-1H,3H-2-thia5a-azacyclopenta[b] anthracen-6-one (AD4) is comparatively stronger than quercetin. Further, immunological and toxicological studies must be carried out to establish the potential as a lead compound or the acetylated derivative tested in vivo to understand the biochemical interactions.

\section{Additional Points}

Supporting information including UV-Vis, GC-MS, and 1D and 2D NMR spectra of compounds $\mathrm{AD}(\mathbf{1}-\mathbf{4})$ are available as supplementary material.

\section{Conflicts of Interest}

The authors declare no conflicts of interest.

\section{Acknowledgments}

The authors appreciate the Directorate of Research, Vaal University of Technology, and Northwest University, South Africa, for providing the facilities for the experiment.

\section{References}

[1] H. H. Kopelson, "The impacts of invasive plant species on human health," in SUNY College of Environmental Science and Forestry Digital Commons @ ESF, 2014, http://digitalcommons .esf.edu/citywild/6.

[2] M. H. Williamson, doi.org/10.1016/j.crvi.2010.12.008, Chapman and Hall, New York, NY, USA, 1996.

[3] L. J. Olson, "The economics of terrestrial invasive species: a review of the literature," Agricultural and Resource Economics Review, vol. 35, no. 1, pp. 178-194, 2006.

[4] U. Quattrocchi, CRC World Dictionary of Grasses, CRC Press, 2006.

[5] Department of Basic Education, "Government Gazette Staatskoerant," Government Gazette, vol. 583, no. 37230, pp. $1-4,2014$.

[6] B. Schreiner, "Water pricing: the case of South Africa," in Water Pricing Experiences and Innovations, A. Dinar, V. Pochat, and J. Albiac-Murillo, Eds., vol. 9 of Global Issues in Water Policy, pp. 289-311, Springer, Cham, 2015.

[7] W. J. Clinton, “Invasive Species,” Federal Register, 1999, https:// www.nwf.org/Wildlife/Threats-to-Wildlife/Invasive-Species.aspx.

[8] F. Pourmorad, S. J. Hosseinimehr, and N. Shahabimajd, “Antioxidant activity, phenol and flavonoid contents of some selected Iranian medicinal plants," African Journal of Biotechnology, vol. 5, no. 11, pp. 1142-1145, 2006.

[9] E. M. Anam, "Novel diterpenoids from acacia decurrens (Fabaceae)". Indian Journal of Chemistry Section B," Indian Journal of Chemistry Section B, Organic Including Medicinal, vol. 37, no. 12, pp. 1307-1309, 1998, https://eurekamag.com/research/ 003/215/003215125.php.

[10] A. Tewari and V. K. Jindal, "Studies on uronic acid materials and structure of Acacia decurrens gum polysaccharide," Journal of Chemical and Pharmaceutical Research, vol. 2, pp. 233-239, 2010, http://www.jocpr.com/.

[11] U. P. Albuquerque, P. M. de Medeiros, M. A. Ramos et al., "Are ethnopharmacological surveys useful for the discovery and development of drugs from medicinal plants?" Brazilian Journal of Pharmacognosy, vol. 24, no. 2, pp. 110-115, 2014. 
[12] Q. V. Vuong, S. Hirun, P. D. Roach, M. C. Bowyer, P. A. Phillips, and C. J. Scarlett, "Effect of extraction conditions on total phenolic compounds and antioxidant activities of Carica papaya leaf aqueous extracts," Journal of Herbal Medicine, vol. 3, no. 3, pp. 104-111, 2013.

[13] J. Zhishen, T. Mengcheng, and W. Jianming, "The determination of flavonoid contents in mulberry and their scavenging effects on superoxide radicals," Food Chemistry, vol. 64, no. 4, pp. 555559, 1999.

[14] R. Singh, P. Verma, and G. Singh, "Total phenolic, flavonoids and tannin contents in different extracts of artemisia absinthium," Journal of Intercultural Ethnopharmacology, vol. 1, no. 2, pp. 101-104, 2012.

[15] S. Fazel, M. Hamidreza, G. Rouhollah, and M. Verdian-Rizi, "Spectrophotometric determination of total alkaloids in some Iranian medicinal plants," Journal of Applied Horticulture, vol. 12, no. 1, pp. 69-70, 2010.

[16] H. P. Makkar, P. Siddhuraju, and K. Becker, "Methods in molecular biology: plant secondary metabolites," Plant Secondary Metabolites, vol. 393, pp. 47-49, 2007.

[17] H. Leffmann, "A text-book of pharmacognosy," Journal of the Franklin Institute, vol. 192, no. 5, pp. 690-691, 1921.

[18] J. H. Jorgensen and J. D. Turnidge, "Antibacterial susceptibility tests: dilution and disk diffusion methods," in Manual of Clinical Microbiology, pp. 1152-1172, ASM Press.11521172, Washington, DC, USA, 9th edition, 2007.

[19] C. O. Wilke, "Robustness and Evolvability in Living Systems," BioScience, vol. 56, no. 8, pp. 695-696, 2006.

[20] M. D. Mukhtar and A. Tukur, "Antimicrobial activity of extracts of pistia strtatiotes L," Journal of the Nigerian Society for Experimental Biology, vol. 1, no. 1, pp. 51-60, 2000.

[21] M. R. S. Zaidan, A. Noor Rain, A. R. Badrul, A. Adlin, A. Norazah, and I. Zakiah, "In vitro screening of five local medicinal plants for antibacterial activity using disc diffusion method," Tropical Biomedicine, vol. 22, no. 2, pp. 165-170, 2005.

[22] I. Wiegand, K. Hilpert, and R. E. W. Hancock, "Agar and broth dilution methods to determine the minimal inhibitory concentration (MIC) of antimicrobial substances," Nature Protocols, vol. 3, no. 2, pp. 163-175, 2008.

[23] M. S. Blois, "Antioxidant determinations by the use of a stable free radical," Nature, vol. 181, no. 4617, pp. 1199-1200, 1958.

[24] P. Siddhuraju and S. Manian, "The antioxidant activity and free radical-scavenging capacity of dietary phenolic extracts from horse gram (Macrotyloma uniflorum (Lam.) Verdc.) seeds," Food Chemistry, vol. 105, no. 3, pp. 950-958, 2007.

[25] M. Bhebhe, T. N. Füller, B. Chipurura, and M. Muchuweti, "Effect of solvent type on total phenolic content and free radical scavenging activity of black tea and herbal infusions," Food Analytical Methods, vol. 9, no. 4, pp. 1060-1067, 2016.

[26] T. Dhanani, S. Shah, N. A. Gajbhiye, and S. Kumar, "Effect of extraction methods on yield, phytochemical constituents and antioxidant activity of Withania somnifera," Arabian Journal of Chemistry, vol. 10, no. 1, pp. S1193-S1199, 2013.

[27] I. C. W. Arts and P. C. H. Hollman, "Polyphenols and disease risk in epidemiologic studies 1-4," American Journal of Clinical Nutrition, vol. 81, pp. 317-325, 2005.

[28] B. Manjunatha, "Antibacterial activity of Pterocarpus santalinus," Indian Journal of Pharmaceutical Sciences, vol. 68, no. 1, pp. 115-116, 2006.

[29] W. R. Elliot and D. L. Jones, Encyclopaedia of Australian plants suitable for cultivation, Lothian Press, Port Melbourne, Australia, 2nd edition, 2002.
[30] A. H. M. M. Rahman, "Traditional medicinal plants used in the treatment of different skin diseases of santals at abdullahpur village under akkelpur upazilla of joypurhat district , Bangladesh," Gloss. Indian Med. Plants, vol. 1, no. 2, pp. 17-20, 2013.

[31] G. C. Omojate, F. O. Enwa, A. O. Jewo, and C. O. Eze, "Mechanisms of Antimicrobial Actions of Phytochemicals against Enteric Pathogens A-Review," J. Pharm. Chem. Biol. Sci, vol. 2, no. 2, pp. 77-85, 2014.

[32] M. A. Soobrattee, V. S. Neergheen, A. Luximon-Ramma, O. I. Aruoma, and T. Bahorun, "Phenolics as potential antioxidant therapeutic agents: Mechanism and actions," Mutation Research-Fundamental and Molecular Mechanisms of Mutagenesis, vol. 579, no. 1-2, pp. 200-213, 2005.

[33] C. M. Simões and E. P. Schenkel, "A pesquisa e a produção brasileira de medicamentos a partir de plantas medicinais: a necessária interação da indústria com a academia," Revista Brasileira de Farmacognosia, vol. 12, no. 1, pp. 35-40, 2002.

[34] W. C. Dornas, T. T. Oliveira, R. G. Rodrigues-das-Dores, A. F. Santos, and T. J. Nagem, "Flavonóides: potencial terapêutico no estresse oxidativo," Revista de Ciências Farmacêuticas Básica e Aplicada, vol. 28, no. 31, pp. 241-249, 2007.

[35] K. Bush, “The ABCD's of $\beta$-lactamase nomenclature," Journal of Infection and Chemotherapy, vol. 19, no. 4, pp. 549-559, 2013.

[36] K. Bush and G. A. Jacoby, "Updated functional classification of beta-lactamases," Antimicrobial Agents and Chemotherapy, vol. 54, no. 3, pp. 969-976, 2010.

[37] C. L. Greenblatt, J. Baum, B. Y. Klein, S. Nachshon, V. Koltunov, and R. J. Cano, "Micrococcus luteus - Survival in amber," Microbial Ecology, vol. 48, no. 1, pp. 120-127, 2004.

[38] C. G. Ramos, S. A. Sousa, A. M. Grilo, J. R. Feliciano, and J. H. Leitão, "The second RNA chaperone, Hfq2, is also required for survival under stress and full virulence of Burkholderia cenocepacia J2315," Journal of Bacteriology, vol. 193, no. 7, pp. 1515-1526, 2011.

[39] C. W. Choi, S. C. Kim, S. S. Hwang et al., "Antioxidant activity and free radical scavenging capacity between Korean medicinal plants and flavonoids by assay-guided comparison," Plant Science, vol. 163, no. 6, pp. 1161-1168, 2002.

[40] S. B. Nimse and D. Pal, "Free radicals, natural antioxidants, and their reaction mechanisms," RSC Advances, vol. 5, no. 35, pp. 27986-28006, 2015.

[41] V. Krishnamachari, L. H. Levine, and P. W. Paré, "Flavonoid oxidation by the radical generator AIBN: a unified mechanism for quercetin radical scavenging," Journal of Agricultural and Food Chemistry, vol. 50, no. 15, pp. 4357-4363, 2002. 

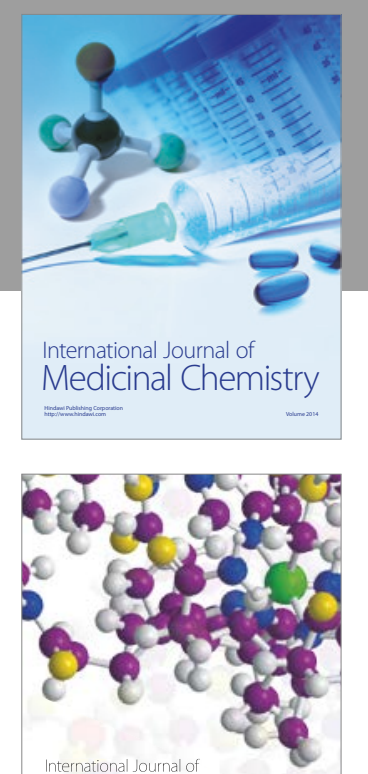

Carbohydrate Chemistry

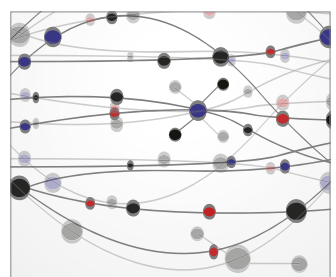

The Scientific World Journal
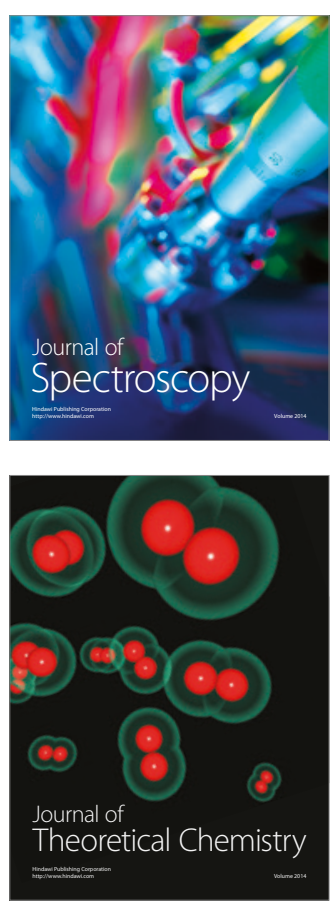
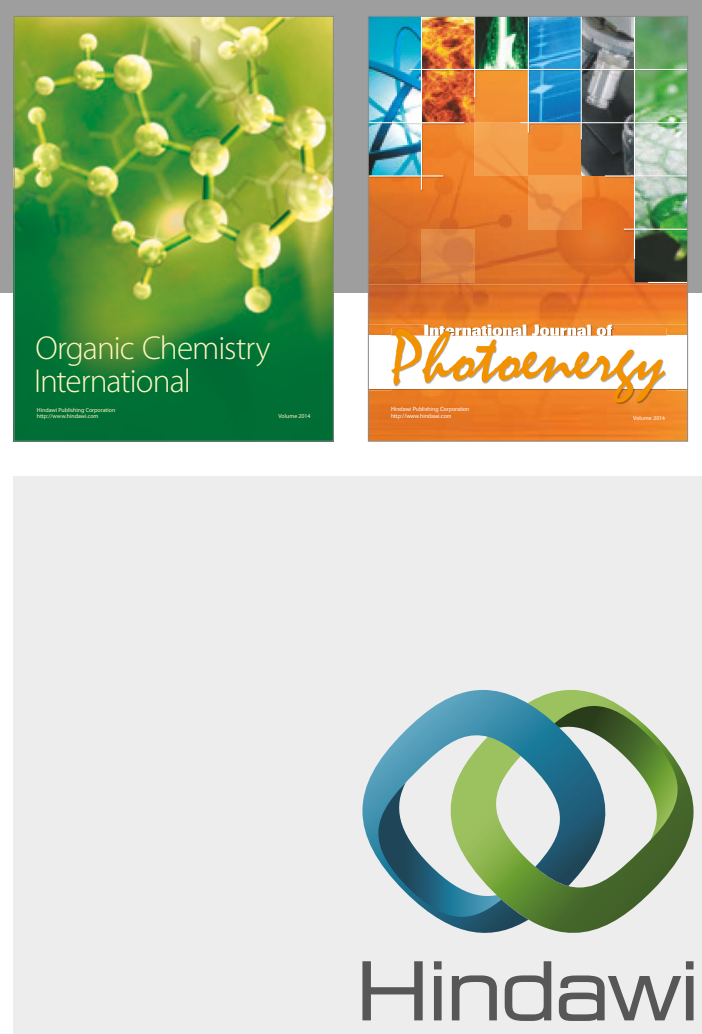

Submit your manuscripts at

https://www.hindawi.com

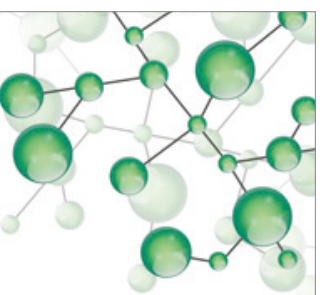

International Journal of

Inorganic Chemistry

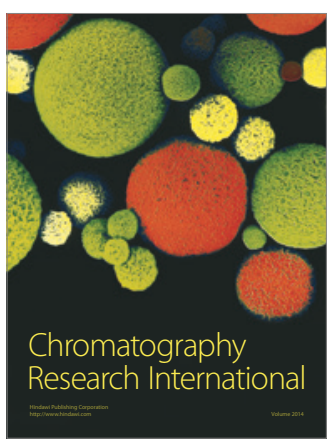

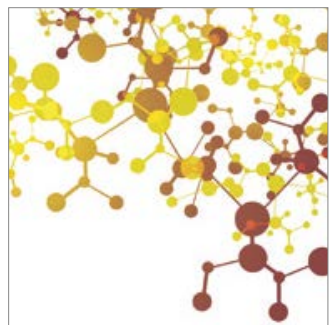

Applied Chemistry
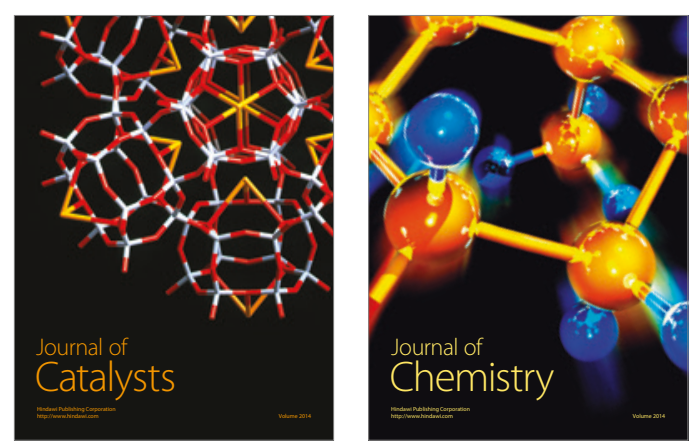
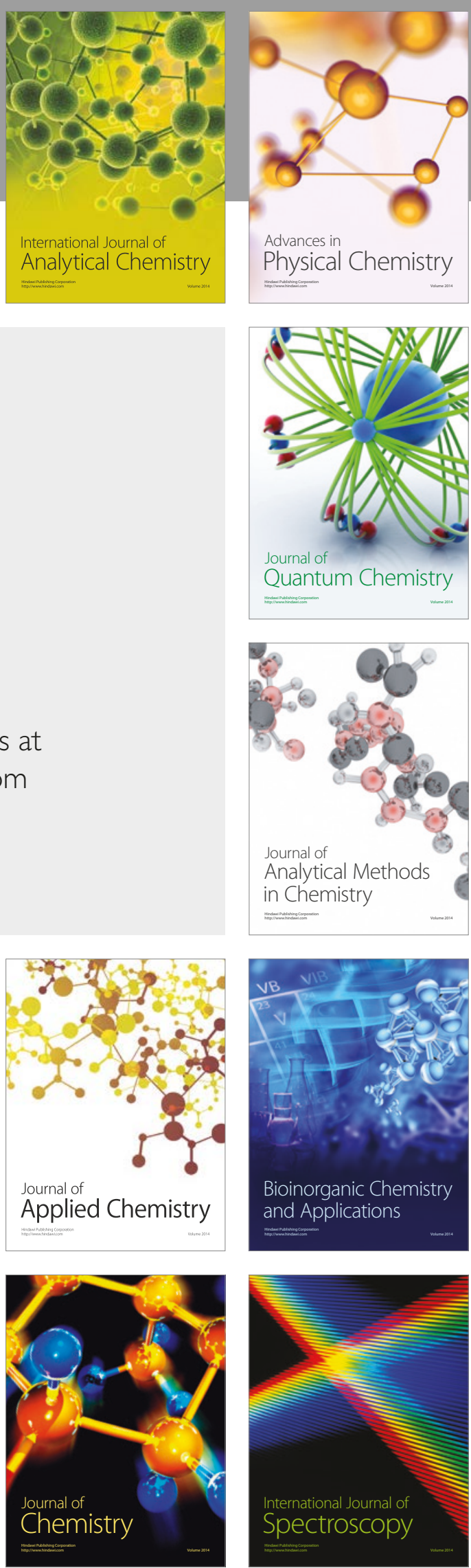